\title{
Root biomass and production of cotton cultivars subjected to saline water irrigation
}

\author{
André Alisson Rodrigues da Silva*, Márcia Cristina de Araújo Pereira, Luana Lucas de Sá Almeida Veloso, \\ Ronaldo do Nascimento, Elka Costa Santos Nascimento, Carlos Vailan de Castro Bezerra, Mateus Costa \\ Batista, Robson Felipe de Lima
}

\author{
Federal University of Campina Grande, Academic Unit of Agricultural Engineering, Campina Grande, \\ 58.109-970, Paraíba, Brazil
}

\section{*Corresponding author: andrealisson_cgpb@hotmail.com}

\section{Abstract}

Water scarcity and high levels of salinity in irrigation water limit irrigated cotton cultivation in the semiarid region of Northeast Brazil. So, it is necessary to adopt cultivation strategies that make the production system feasible. In this context, the present study aimed to evaluate the biomass and production of cotton cultivars subjected to different levels of saline water irrigation. The experiment was carried out under greenhouse conditions, with treatments distributed in a completely randomized design, in a $5 \times 2$ factorial arrangement, corresponding to five levels of irrigation water electrical conductivity - ECW $\left(1.5,3.0,4.5,6.0\right.$ and $\left.7.5 \mathrm{dS} \mathrm{m} \mathrm{m}^{-1}\right)$ and two cotton cultivars (BRS 368 RF and BRS Safira), with 4 replicates. Treatment effects were measured by the number of bolls per plant, lint weight, number of seeds per plant, total weight of seeds and dry and fresh biomass of stem, roots and leaves. Irrigation using water with electrical conductivity from $1.5 \mathrm{dS} \mathrm{m}^{-1}$ negatively affects the production of the cotton cultivars BRS SAFIRA and BRS $368 \mathrm{RF}$, causing reductions in all production variables analyzed. The cultivar BRS Safira has better production performance than BRS 368 RF when exposed to water salinity.

Keywords: Gossypium hirsutum, salt stress, BRS Safira.

Abbreviations: DAS_ days after sowing; ECW_ irrigation water electrical conductivity; LFB_leaf fresh biomass; SFB_ stem fresh biomass; RFB_ root fresh biomass; LDB_leaf dry biomass; SDB_ stem dry biomass; RDB_ root dry biomass; NBP_ number of bolls per plant, NSP_number of seeds per plant; LW_lint weight; TWS_total weight of seeds.

Introduction

The Brazilian semiarid region is characterized by the occurrence of precipitations that are unevenly distributed in time and space. Due to these hydrologic characteristics, the use of water with high levels of salinity to irrigate crops has become common. Thus, excess of salts in the rhizosphere became a fundamental problem for the agricultural development in the region (Souza et al., 2018a). Usually, reductions in the yield of plants in intensely salinized environments can be partially attributed to limitations in their physiological processes, due to the decrease in the osmotic potential of the soil solution and to the phytotoxic and nutritional effects. In addition, the high levels of salts in the soil solution alter the capacity of plants to absorb, transport and use the ions required for their development and production (Peng et al., 2016; Soares et al., 2018a). Cotton plants are able to adapt to the edaphoclimatic conditions of the semiarid region, because their threshold salinity is the electrical conductivity of $5.1 \mathrm{dS} \mathrm{m}^{-1}$ in irrigation water, which characterizes them as tolerant to salinity. However, it is important to emphasize that plant tolerance varies between species and/or genotypes of a species, or even between the phenological stages of the same genotype (Lima et al., 2019; Oliveira et al., 2013). Some studies conducted with naturally colored cotton, such as BRS Jady
(Souza et al., 2018a), BRS Topázio (Silva et al., 2017) and BRS Rubi (Lima et al., 2017), have reported negative effects of salinity on growth and production. However, a study carried out with the cultivar RBS Safira showed good performance in terms of growth under high salinity compared to the whitefiber cotton cultivar (Silva et al., 2019). In this context, conducting a study to identify cultivars that achieve a viable production in saline environment is extremely important for the development of agricultural exploitation in the semiarid region and creation of new salt-tolerant plant materials. In this context, the present study aimed to evaluate the biomass and production of cotton cultivars subjected to different levels of irrigation water salinity.

\section{Results and discussion}

Effect of irrigation with saline water on the biomass of cotton cultivars

The $F$ test (Table 1$)$ shows significant effects $(p<0.01)$ of the levels of irrigation water salinity on all variables analyzed, except for leaf fresh biomass (LFB). In relation to the cotton cultivars, a significant effect $(p<0.01)$ was observed only for leaf fresh biomass (LFB) and stem dry biomass (SDB). The 
interaction between the studied factors did not significantly affect any of the variables analyzed.

Leaf fresh biomass differed significantly between the cotton cultivars. According to the means comparison test, the cultivar BRS Safira had higher value of LFB, with a difference of $17.87 \mathrm{~g}$ compared to the cultivar BRS $368 \mathrm{RF}$ (Figure 1A). In view of the results, it is possible to state that the cultivar BRS 368 RF was more hampered with the exposure to salt stress, showing to be more sensitive to salinity than the cultivar BRS Safira.

Irrigation using water with increasing salinity levels negatively affected leaf dry biomass, which decreased linearly according to the regression equation (Figure 1B), with maximum LDB production ( $17.74 \mathrm{~g}$ ) estimated in plants irrigated with $1.5 \mathrm{dS} \mathrm{m}^{-1}$ water, which tended to decrease from this ECW level by $4.29 \%$ per unit increase in ECW. A reduction of $4.89 \mathrm{~g}(27.56 \%)$ in LDB was obtained in plants subjected to the highest salinity level, compared to those under ECW of $1.5 \mathrm{dS} \mathrm{m}^{-1}$.

The increase in ECW negatively affected stem fresh biomass (Figure 2A) and dry biomass (Figure 2B). Based on the regression equations, SFB and SDB decreased by $8.26 \%$ and $9.45 \%$, respectively, per unit increase in $E C W$ in the evaluation performed at 140 DAS. In a study conducted by Capitulino et al. (2017) using the cotton cultivar BRS Topázio under salt stress ( 1.5 to $6.0 \mathrm{dS} \mathrm{m}^{-1}$ ), the authors attributed the reduction of plant biomass to the negative effects of salinity, which are associated with its interference in the processes of net $\mathrm{CO}_{2}$ assimilation, translocation of carbohydrates to sink tissues, and diversion of energy sources to other processes, such as: osmotic adjustment, synthesis of compatible solutes, repair of damage caused by salinity and maintenance of basic metabolic processes.

Following the same trend observed for SFB and SDB (Figures $2 \mathrm{~A}$ and $2 \mathrm{~B}$ ), the data of root fresh and dry biomass also fitted to the decreasing linear regression model (Figure $3 \mathrm{~A}$ and $3 B$ ), with reductions of 9.70 and $10.67 \%$ per unit increase in $\mathrm{ECW}$ for RFB and RDB, respectively, which correspond to reductions of $13.37 \mathrm{~g}$ in the RFB and $6.63 \mathrm{~g}$ in the RDB of plants irrigated using water with $\mathrm{ECW}$ of $7.5 \mathrm{dS} \mathrm{m^{-1 }}$ compared to those under ECW of $1.5 \mathrm{dS} \mathrm{m}^{-1}$.

According to Kong et al. (2017), the reductions in root biomass under saline conditions lead to a lower absorption of water and nutrients, as a consequence of the decrease in the root absorption zone, thus leading to stresses that will affect production.

\section{Irrigation water salinity affects on the production of cotton cultivars}

Based on the $F$ test (Table 2), the interaction between the studied factors was significant for number of bolls per plant (NBP), number of seeds per plant (NSP) and lint weight (LW). The single factors levels of irrigation water salinity and cultivar had significant $(p<0.01)$ effects on all variables analyzed.

Figure 4A shows that the increase in irrigation water electrical conductivity negatively affected the number of bolls in the cotton cultivars studied. According to the regression equation, there was a linear effect, with reductions of 9.85 and $9.36 \%$ per unit increase in $\mathrm{ECW}$ in plants of the cultivars BRS Safira and BRS 368 RF, respectively. This result is consistent with those reported by Silva et al. (2017), who studied the effect of water salinity ( $E C W$ of $1.5 ; 3.0 ; 4.5$ and $6.0 \mathrm{dS} \mathrm{m}^{-1}$ ) on the cultivation of the cotton cultivar BRS Topázio and observed a $12.83 \%$ reduction in the number of bolls per unit increase in ECW. Despite the reduction in the number of bolls with the increment in water salinity, plants of the cultivar BRS Safira had higher number of bolls than plants of the cultivar BRS 368 RF.

The unit increase in irrigation water electrical conductivity caused a linear reduction in the number of seeds of both cotton cultivars (Figure 4B). A comparison between the results obtained in plants irrigated using water of highest and lowest salinity levels ( 7.5 and $1.5 \mathrm{dS} \mathrm{m}^{-1}$, respectively) showed reductions of $82.98 \%$ ( 130.4 seeds) in the cultivar BRS Safira and $87.37 \%$ ( 99.6 seeds) in the cultivar BRS 368 RF. As observed in the number of bolls (Figure 1A), BRS Safira plants outperformed BRS 368 RF plants, since they obtained a higher number of seeds under all levels of salinity.

The reductions in the number of bolls and number of seeds with the increase in irrigation water salinity were observed in both BRS Safira and BRS 368 RF. It can be attributed to the reduction of osmotic potential caused by the concentration of soluble salts in the soil and metabolic disorders, mainly related to the absorption of water and nutrients by plants (Oliveira et al., 2012).

According to Figure $4 \mathrm{C}$, the interaction between the factors irrigation water salinity and cotton cultivars negatively affected lint weight. Plants of the cultivar BRS Safira had a reduction in the $\mathrm{LW}$ of $12.52 \%$ per unit increase in $\mathrm{ECW}$, i.e., reduction of $92.51 \%(10.50 \mathrm{~g})$ in the LW of plants irrigated using water with the highest level of salinity $\left(7.5 \mathrm{dS} \mathrm{m}^{-1}\right)$ compared to those under the lowest level $\left(1.5 \mathrm{dS} \mathrm{m}^{-1}\right)$. It can also be noted that plants of the cultivar BRS $368 \mathrm{RF}$ obtained lower values of LW compared to BRS Safira under all levels of salinity, but there was a reduction of $95.24 \%(8.52 \mathrm{~g})$ in the LW of plants of the cultivar BRS 368 RF under irrigation using water with the highest level of salinity, compared to the lowest level. This result shows that the cultivar BRS 368 $\mathrm{RF}$ has greater sensitivity to irrigation water salinity.

A study conducted by Soares et al. (2018b), using different cotton genotypes under levels of irrigation water salinity and management strategies, also found a reduction in lint weight in response to water salinity, which was attributed to the lower water absorption by plants under salt stress, due to the lower soil water potential.

By analyzing the single effect of the cultivars on the total weight of seeds (TWS), it was possible to note that, according to the means comparison test (Figure 4D), that BRS Safira obtained higher value of TWS (7.76 g), which was $49.1 \%$ higher than that of the cultivar BRS 368 RF. Hence, it is possible to infer that, although irrigation water salinity directly affects production, the cultivars do not respond equally to the deleterious effects of salinity, because some are more tolerant than others (Lima et al., 2019).

The unit increase in irrigation water electrical conductivity negatively affected the total weight of seeds (Figure 4E) and, according to the regression equation, there was a linear reduction in the total weight of seeds. By comparing the 
Table 1. Summary of the $F$ test for leaf fresh biomass (LFB), leaf dry biomass (LDB), stem fresh biomass (SFB), stem dry biomass (SDB), root fresh biomass (RFB) and root dry biomass (RDB) of cotton cultivars irrigated with saline water.

\begin{tabular}{lllllll}
\hline \multirow{2}{*}{ Source of variation } & \multicolumn{7}{c}{ F-Test } \\
\cline { 2 - 7 } & LFB & LDB & SFB & SDB & RFB & RDB \\
\hline Salinity Level (SL) & ns & $* *$ & $* *$ & $* *$ & $* *$ & $* *$ \\
Linear regression & $\mathrm{ns}$ & $* *$ & $* *$ & $* *$ & $* *$ & $* *$ \\
Quadratic regression & $\mathrm{ns}$ & $\mathrm{ns}$ & $\mathrm{ns}$ & $\mathrm{ns}$ & $\mathrm{ns}$ & $\mathrm{ns}$ \\
Cultivar & $* *$ & $\mathrm{~ns}$ & $\mathrm{~ns}$ & $\mathrm{~ns}$ & $\mathrm{~ns}$ & $* *$ \\
Interaction (SL x Cultivar) & $\mathrm{ns}$ & $\mathrm{ns}$ & $\mathrm{ns}$ & $\mathrm{ns}$ & $\mathrm{ns}$ & $\mathrm{ns}$ \\
\hline CV (\%) & 15.86 & 16.39 & 15.17 & 22.63 & 28.02 & 19.01 \\
\hline $\mathrm{ns}, * * *$
\end{tabular}

not significant, significant at $p<0.01$ and $p<0.05$, respectively.


Fig 1. Leaf fresh biomass - LFB (A) as a function of the cultivars and leaf dry biomass - LDB (B) as a function of irrigation water salinity (B).

Table 2. Summary of the $F$ test for the number of bolls per plant (NBP), number of seeds per plant (NSP), lint weight (LW) and total weight of seeds (TWS) of the cotton cultivars irrigated with saline water.

\begin{tabular}{|c|c|c|c|c|}
\hline \multirow{2}{*}{ Fonte de variação } & \multicolumn{4}{|l|}{ Test $\mathrm{F}$} \\
\hline & NBP & NSP & LW & TWS \\
\hline Salinity Level (SL) & $* *$ & $* *$ & $* *$ & $* *$ \\
\hline Linear regression & $* *$ & $* *$ & $* *$ & $* *$ \\
\hline Quadratic regression & ns & ns & ns & ns \\
\hline Cultivar & $* *$ & $* *$ & $* *$ & $* *$ \\
\hline Interaction (SL x Cultivar) & $*$ & $* *$ & $* *$ & ns \\
\hline CV (\%) & 22.00 & 13.03 & 15.87 & 20.92 \\
\hline
\end{tabular}
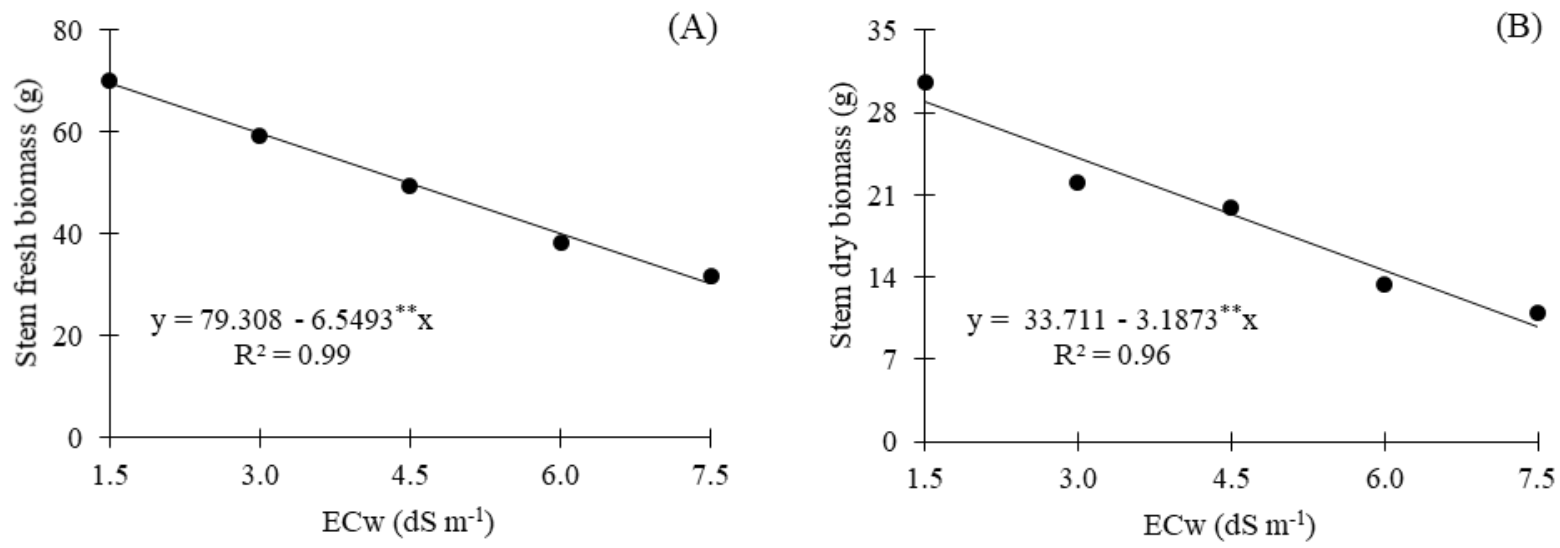

Fig 2. Stem fresh biomass - SFB (A) and stem dry biomass - SDB (B) as a function of irrigation water salinity. 

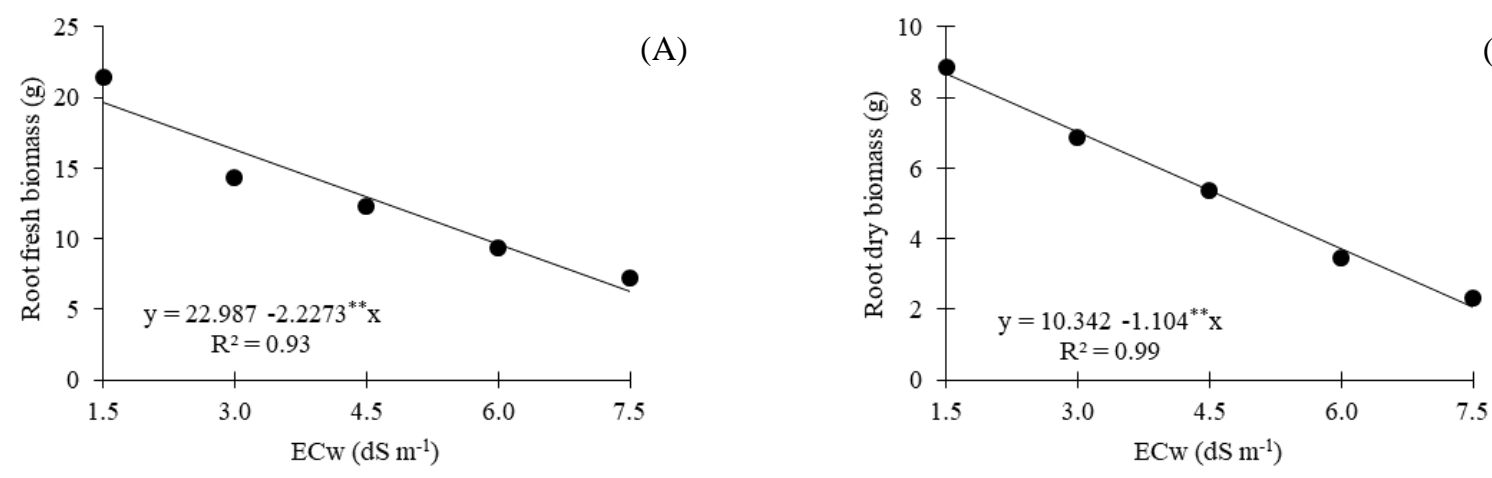

(B)

Fig 3. Root fresh biomass - RFB (A) and root dry biomass - RDB (B) as a function of irrigation water salinity.
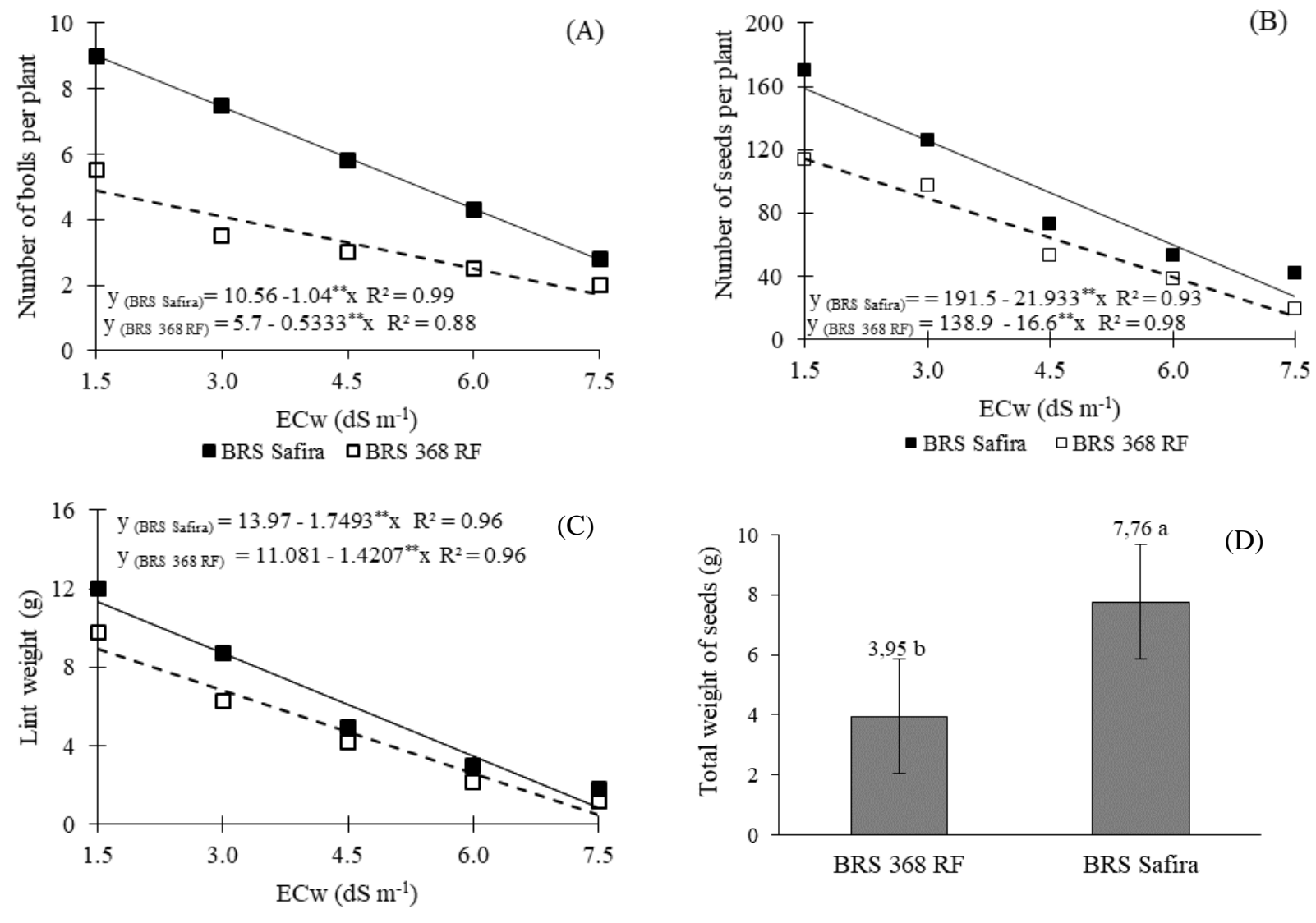

- BRS Safira aBRS 368 RF

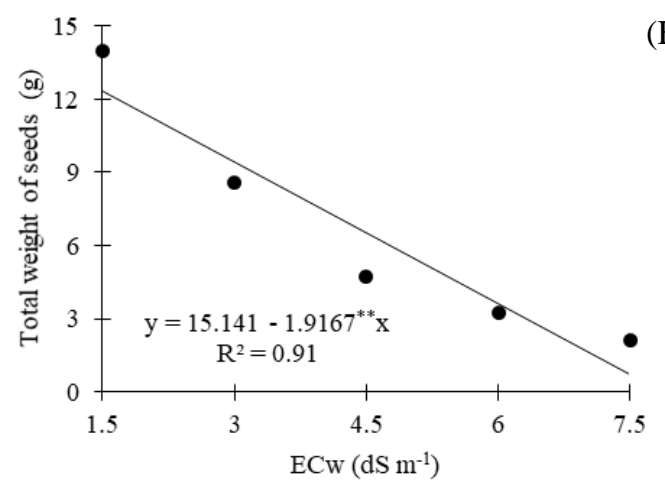

(E)

Fig 4. Number of bolls per plant - NBP (A); number of seeds per plant - NSP (B) and lint weight - LW (C) as a function of the interaction between irrigation water salinity and cotton cultivars; total weight of seeds - TWS as a function of cultivars (D) and irrigation water salinity (E). 
results obtained in plants irrigated using water of highest and lowest levels of salinity $\left(7.5\right.$ and $1.5 \mathrm{dS} \mathrm{m} \mathrm{m}^{-1}$, respectively), there was a reduction of $93.76 \%(11.50 \mathrm{~g})$. Jácome et al. (2003), working with different cotton genotypes, also observed a reduction in the production parameters in response to increased salinity.

\section{Materials and methods}

\section{Location and treatments}

The study was conducted during the period from November 2017 to March 2018, in plastic pots adapted as drainage lysimeters under greenhouse conditions at the Center for Technology and Natural Resources of the Federal University of Campina Grande, municipality of Campina Grande, PB, in the Agreste Paraibano mesoregion, Brazil (7ㅇ 15' 18" S; 35은 $52^{\prime} 28^{\prime \prime}$ W; altitude of $550 \mathrm{~m}$ ).

The treatments resulted from the combination of five levels of irrigation water electrical conductivity - $\operatorname{ECW}(1.5,3.0$, 4.5, 6.0 and $7.5 \mathrm{dS} \mathrm{m}^{-1}$ ) and two cotton cultivars (BRS $368 \mathrm{RF}$ and BRS Safira), distributed in a completely randomized design in a $5 \times 2$ factorial scheme, with four replicates.

\section{Experimental setup and conduction}

The different levels of irrigation water electrical conductivity were established based on the threshold salinity of the cotton crop, $5.1 \mathrm{dS} \mathrm{m}^{-1}$ in irrigation water (Sousa et al., 2018), and prepared by the addition of sodium chloride $(\mathrm{NaCl})$ in water from the local supply system $(\mathrm{EC}=0.8 \mathrm{dS} \mathrm{m}$ $\left.{ }^{1}\right)$, using the relationship between $\mathrm{ECW}$ and the concentration of salts $\left(10^{*} \mathrm{mmol}_{\mathrm{c}} \mathrm{L}^{-1}=\mathrm{ECW} \mathrm{dS} \mathrm{m}^{-1}\right)$ recommended by Richards (1954). $\mathrm{NaCl}$ was used because it is the salt present at highest concentration in the water sources of the semiarid region and for causing more significant damage to crops.

Plants were grown in plastic pots filled with a $0.3-\mathrm{kg}$-thick layer of crushed stone covering the bottom of the lysimeter and $18 \mathrm{~kg}$ of a soil classified as sandy loam Neossolo Regolítico (Entisol) collected in the $0-20 \mathrm{~cm}$ layer, in the rural area of the municipality of Lagoa Seca, PB, which properly pounded to break up clods and sieved. The physicalhydraulic and chemical characteristics were determined according to methodologies proposed by Teixeira et al. (2017) as follows: $\mathrm{Ca}^{2+}, \mathrm{Mg}^{2+}, \mathrm{Na}^{+}, \mathrm{K}^{+},\left(\mathrm{Al}^{3+}+\mathrm{H}^{+}\right)=2.60$; 3.66; $0.16 ; 0.22$ and $1.93 \mathrm{cmol}_{\mathrm{c}} \mathrm{kg}^{-1}$, respectively; $\mathrm{pH}$ (water $1: 2.5$ ) $=5.9$; $\mathrm{ECse}\left(\mathrm{dS} \mathrm{m}^{-1}\right)=1.0$; organic matter $(\%)=1.36$; sand, silt and clay $=733,142$ and $125 \mathrm{~g} \mathrm{~kg}^{-1}$, respectively; bulk density $\left(\mathrm{kg} \mathrm{dm}^{-3}\right)=1.39$; moisture contents at pressures 33.42 and $1519.5 \mathrm{kPa}=11.98$ and $4.32 \mathrm{dag} \mathrm{kg}^{-1}$, respectively. After filling the pots, soil moisture content was raised to the level of field capacity and maintained throughout the experiment by daily irrigations, applying in each pot the solutions corresponding to the treatments. The volume applied was estimated by water balance: water volume applied minus water volume drained in the previous irrigation, plus a leaching fraction of 0.15 in order to avoid excessive accumulation of salts in the soil.

Sowing was carried out on November 10 , by planting four seeds per pot at $1.5 \mathrm{~cm}$ depth. At 20 days after sowing (DAS), thinning was performed leaving only the most vigorous seedling.
Fertilization with nitrogen (N), phosphorus (P) and potassium (K) was performed as top-dressing, as recommended by Novais et al. (1991), applying $4.0 \mathrm{~g}$ of urea, $4.5 \mathrm{~g}$ of potassium chloride and $10.8 \mathrm{~g}$ of monoammonium phosphate, equivalent to 100,150 and $300 \mathrm{mg} \mathrm{kg}^{-1}$ of soil of $\mathrm{N}, \mathrm{K}_{2} \mathrm{O}$ and $\mathrm{P}_{2} \mathrm{O}_{5}$, respectively. Phosphorus was applied at planting and potassium as top-dressing through fertigation, split into two equal portions, applied at 45-day intervals, with the first application performed one day before sowing. Nitrogen was split into 3 applications, with the first one at 30 days after sowing, at 30-day intervals. Urea, monoammonium phosphate and potassium chloride were used as the sources of $\mathrm{N}, \mathrm{P}$ and $\mathrm{K}$, respectively. In order to meet the requirements of micronutrients, $2.5 \mathrm{~g} \mathrm{~L}^{-1}$ of Ubyfol were applied on the leaves, every 15 days, according to the manufacturer's recommendation [ $\left(\mathrm{N}(15 \%) ; \mathrm{P}_{2} \mathrm{O}_{5}(15 \%) ; \mathrm{K}_{2} \mathrm{O}\right.$ (15\%); Ca (1\%); Mg (1.4\%); S (2.7\%); Zn (0.5\%); B (0.05\%); Fe (0.5\%); $\mathrm{Mn}(0.05 \%) ; \mathrm{Cu}(0.5 \%) ; \mathrm{Mo}(0.02 \%)]$.

\section{Variables analyzed}

At 140 DAS, plants were subjected to the evaluation of the following parameters: leaf fresh biomass (LFB), stem fresh biomass ( $\mathrm{SFB}$ ), root fresh biomass (RFB), leaf dry biomass (LDB), stem dry biomass (SDB), root dry biomass (RDB), number of bolls per plant (NBP), number of seeds per plant (NSP), lint weight (LW) and total weight of seeds (TWS). For fresh biomass determination, plants were collected, separated into different parts (roots, stem and leaves) and weighed. After fresh biomass determination, the different parts (roots, stem and leaves) were placed in paper bags and dried in a forced air circulation oven at temperature of 65 oC, until constant weight. Then, the material was weighed to obtain leaf dry biomass, stem dry biomass and root dry biomass. The bolls were harvested from each plant as they reached the harvesting point. After that, the seeds were removed in order to quantify the number of seeds per plant and determine the total weight of seeds and lint weight using a $0.001 \mathrm{~g}$ precision scale.

\section{Statistical analysis}

The obtained data were evaluated by analysis of variance by $F$ test at 0.05 and 0.01 probability levels and, in cases of significance, linear and quadratic polynomial regression analysis was carried out for the 'salinity' factor, and means comparison test (Tukey) at 0.05 probability level was applied to the 'cultivar' factor, using the statistical program SISVARESAL (Ferreira, 2014).

\section{Conclusions}

Irrigation using saline water with electrical conductivity from $1.5 \mathrm{dS} \mathrm{m}^{-1}$ negatively affects the production of the cotton cultivars BRS Safira and BRS 368 RF, causing reductions in all production variables analyzed.

The cultivar BRS Safira has better production performance than BRS 368 RF when exposed to water salinity.

\section{References}

Capitulino JD, Silva AAR, Lima GS, Nobrega RA, Nascimento HM, Soares LAA (2017) Aspectos fisiológicos e crescimento 
do algodoeiro 'BRS topázio' cultivado com águas salinas e adubação potássica. Rev Verde de Agroec e Desenvolv Sustent. 12:267-272.

Ferreira DF (2014) Sisvar: A guide for its bootstrap procedures in multiple comparisons. Ciênc Agrotec. 38:109-112.

Jácome AG, Oliveira RH, Fernandes PD, Gonçalves ACA (2003) Comportamento produtivo de genótipos de algodão sob condições salinas. Acta Sci Agron. 25:187-194.

Kong X., Luo Z., Dong H., Li W., Chen, Y. (2017) Non-uniform salinity in the root zone alleviates salt damage by increasing sodium, water and nutrient transport genes expression in cotton. Sci Rep. 7:2879.

Lima GS, Dias AS, Soares LAA, Gheyi HR, Nobre GR, Souza LP (2017) Growth and yield of colored-fiber cotton grown under salt stress and nitrogen fertilization. Rev Bras Eng Agríc Ambient. 21:415-420.

Lima GS, Dias AS, Soares LAA, Gheyi HR, Nobre RG, Silva, AARD (2019) Phytochemical efficiency, photoassimilate partition and production of cotton under salt stress and nitrogen fertilization. Rev de Ciênc Agrár. 42:211-220.

Novais RF, Neves JCL, Barros NF (1991) Ensaio em ambiente controlado In: Oliveira, AJ. (ed.) Métodos de pesquisa em fertilidade do solo. Brasília: Embrapa SEA. p.189-253.

Oliveira FA, Medeiros JF, Oliveira FRA, Freire AG, Soares LCS (2012) Produção do algodoeiro em função da salinidade e tratamento de sementes com regulador de crescimento. Rev Ciênc Agronôm. 43:279-287.
Oliveira AB de, Alencar NLM, Gomes-Filho, E (2013). Comparison between the water and salt stress effects on plant growth and development. In Sener Akinci, editors. Responses of Organisms to Water Stress, InTech; 2013, p. 67-94.

Peng Z, He S, Sun J, Pan Z, Gong W, Lu Y, Du X (2016) Na+ compartmentalization related to salinity stress tolerance in upland cotton (Gossypium hirsutum) seedlings. Sci Rep, 6:14.

Richards LA (1954) Diagnosis and improvement of saline and alkali soils. Washington: U. S. Department of Agriculture, Agriculture Handbook, p.160, 1954.

Silva AAR, Lima GS, Azevedo CAV, Soares LAA, Gheyi HR, Oliveira RC (2017) Potassium fertilization in the cultivation of colored cotton irrigated with saline water. Rev Bras Eng Agríc Ambient. 21:628-633.

Soares LAA, Fernandes PD, Lima GS, Suassuna JF, Pereira RF (2018a) Gas exchanges and production of colored cotton irrigated with saline water at different phenological stages. Rev Ciênc Agronôm. 49:239-248.

Soares LAA, Fernandes PD, Lima GS, Brito MEB, Nascimento RD, Arriel NHC (2018b) Physiology and production of naturally-colored cotton under irrigation strategies using salinized water. Pesq Agropec Bras. 53:746-755.

Souza LP, Lima GS, Gheyi HR, Nobre RG, Soares LAA (2018) Emergence, growth, and production of colored cotton subjected to salt stress and organic fertilization. Rev Caatinga. 31:719-729.

Teixeira PC, Donagema GK, Fontana A, Teixeira WG (org.) (2017) Manual de métodos de análise de solo. 3.ed. Brasília: Embrapa Solos. 